\title{
Novas perspectivas sobre a presença francesa na Bahia em torno de 1798
}

\author{
István Jancsó \\ Marco Morel
}

\section{Introdução}

Os documentos franceses que recentemente chegaram ao conhecimento de pesquisadores sobre os acontecimentos em torno da Bahia de 1798 não só agregam informações aos episódios, como permitem novas interpretações que trazem dimensão até então inédita ou pouco compreendida sobre a chamada Conjuração Baiana ou dos Alfaiates, como tradicionalmente ficou conhecida. Ainda que tais releituras custem a se consolidar nas referências de historiadores e nos materiais didáticos, por exemplo, ou exatamente por isso, justifica-se aqui a publicação de dois destes documentos que são, até agora, os mais substanciais nesse sentido. Trata-se de um Projeto e de uma carta dirigidos às autoridades da República Francesa, de 1797, abordando o mesmo tema e escritas pelo capitão e Chefe de Divisão das Armadas Navais Francesas, Antoine René Larcher (1740-1808). Ou seja: a solicitação de que a França revolucionária realizasse uma intervenção militar e política na Bahia para apoiar a sedição que ali se ensaiava contra a monarquia e o domínio português ${ }^{1}$. São estes documentos que se transcrevem a seguir, em edição bilíngüe (francês e português) com notas explicativas $^{2}$.

O conteúdo dessas cartas abre novas possibilidades para a análise de problemas fundamentais relativos aos eventos que culminaram dramaticamente com o enforcamento, em 8 de novembro de 1799, no Largo da Piedade, em Salvador, dos soldados Luís Gonzaga das Virgens e Veiga e Lucas Dantas do Amorim Torres, do alfaiate João de Deus do Nascimento 
e do quase adolescente Manuel Faustino dos Santos Lira, por crime de sedição. Em primeiro lugar, porque elas acrescentam novas informações sobre dimensóes potencialmente operacionais da francezia atribuída aos envolvidos na conspiração. Em segundo lugar, por aduzirem variáveis até hoje desconhecidas a respeito da circulação social de idéias sediciosas na Bahia do final do século XVIII e, por último, porque iluminam por outro ângulo o recorrente problema historiográfico da abrangência social da sedição intentada na Bahia em 1798, para ficarmos com os termos de Luis Henrique Dias Tavares.

Quanto ao último ponto, nunca é demais lembrar que desde o registro dos contemporâneos - a exemplo de Luis dos Santos Vilhena ${ }^{3}$ e o anônimo autor das Notícias da Bahia ${ }^{4}$, até Armitage ${ }^{5}$ e Varnhagen ${ }^{6}$, a versão canônica dos fatos pautou-se pela circunscrição deles ao universo dos homens de menor valia da Capitania, na esteira do padrão estabelecido por D. Fernando José de Portugal, Governador dela à época dos acontecimentos ${ }^{7}$. E tirante o registro de Accioli em sua obra de cuidadoso cronista, anotando que "disse-se por esta ocasião que pessoas de consideração influíam na pretendida revolta" indiscutido até a revisão historiográfica empreendida, já em contexto republicano, por Francisco Borges de Barros 9 e, em nível de superior qualidade quanto ao trato da documentação pertinente, por Braz do Amaral ${ }^{10}$, ambos argüindo a participação de integrantes da elite baiana na sedição de 1798, no que foram seguidos por outro historiador baiano - Afonso Ruy, autor do mais conhecido e citado estudo entre os que se propuseram a dar conta do que ele, com engajado sentido de marketing político, denominou de "a primeira revolução social brasileira"11.

A tese de Ruy surpreende pela ousadia. Segundo ele, ao ocorrido na Bahia em 1798 "melhor seria chamarmos de Revolução Proletária, atendendo ao ambiente de operários, artesãos e soldados que a propagavam e a orientavam, doutrinados sob os princípios políticos, socialistas e irreligiosos da França ${ }^{12}$ ". O núcleo duro desse fluxo doutrinário era formado por "elementos de maior valor da Capitania, pelo saber e bens de fortuna, [empenhados em] estudar e discutir os problemas políticos e econômicos que revolucionavam o mundo"13, idéias cuja difusão entre homens das classes subalternas revelou-se o ponto fraco da empreitada política devido à perda do controle do processo pelo núcleo bem-pensante. 
A lógica de Ruy é lapidar: no caso da Bahia do final dos setecentos, as idéias da modernidade européia, ao romperem o circuito fechado das elites, liberaram práticas sociais e políticas incompatíveis com os objetivos que as justificavam. Desfeito o nexo organizador da hierarquia entre as classes, o fracasso tornaltornou-se inevitável. Com isso, Ruy deu conta, simultaneamente, da questão da abrangência social dos eventos de 1798, e da lição que eles encerram, recorrendo - et par cause - à autoridade de Gustavo Barroso, para quem "na revolução dos alfaiates se revelaram bem as tendências socialistas não só pelos atos como pelas palavras mal ouvidas e nunca absorvidas" 14 .

O estudo de Affonso Ruy foi submetido a severa crítica por Luís Henrique Dias Tavares, o historiador que certamente mais tempo de pesquisa documental dedicou aos "Alfaiates" 15 , ainda que sua visão geral da configuração social da sedição baiana corresponda, ao fim e ao cabo, ao esquema explicativo básico de quem criticava.

Para Tavares, "dos fins de 1793 para começo de 1794, até julho, agosto-setembro de 1797 , atuou na cidade do Salvador um pequeno grupo de 'homens de consideração', brasileiros que repudiavam a exploração colonial e sentiam atração pela França das idéias democrático-burguesas" ${ }^{16}$. As idéias que entre eles circulavam chegaram a pessoas do comum que se encantaram com elas. A sedição, entendida como a elaboração de um projeto de ação política destinado a alterar as relações de poder vigentes, circunscreveu-se, então, a este meio, o que lhe permitiu afirmar que "homens livres, mas socialmente discriminados, mulatos, soldados, artesãos, ex-escravos e descendentes de escravos, conceberam a idéia de uma república que garantisse igualdade. São eles que estão falando em levante em 1798"17.

$\mathrm{O}$ recurso de circunscrever os fatos a uma tentativa de levante - e à conseqüente repressão na esteira da divulgação dos pasquins revolucionários pela cidade, e do malogro da subseqüente reunião de conspiradores nas cercanias do Dique na noite de 25 de agosto de 1798, levou Tavares, cioso em respeitar os limites da empiria documental que manejava, a abandonar a busca das conexões dos inculpados na Devassa ${ }^{18}$, com os que sabidamente participavam dos persistentes conciliábulos de caráter sedicioso no circuito das elites. Esse viés interpretativo tem sido respaldado por muitos dos historiadores que revisitaram o assunto ${ }^{19}$, o que não impediu 
que Tavares chamasse a atenção para o quanto havia de sugestivo no fato de a maior parte dos escravos, de alguma forma conectados com a Devassa, terem pertencido a José Pires de Carvalho e Albuquerque, Secretário-Geral do Estado do Brasil e da Guerra e proprietário de engenhos de açúcar e currais de gado na Bahia.

Conforme se pode perceber, o legado de D. Fernando José de Portugal, também reforçado pela repercussão de importantes obras de historiadores estrangeiros de grande prestígio ${ }^{20}$, permanece até hoje como um quase irremovível círculo de giz historiográfico, malgrado os esforços para rompê-lo.

O fato é que a circunscrição dos eventos sediciosos aos estratos inferiores da massa de homens livres da Capitania (como querem uns), ou a gentes inseridas nas "categorias médias e baixas" ${ }^{21}$ como outros sustentam, passa ao largo de evidências amplamente disponíveis, a exemplo do já referido registro de Accioli, ou do que está disponível nas "recordações biographicas" do boticário João Ladisláu de Figueiredo e Mello publicadas em $1866^{22}$ ou, ainda, em passagens dispersas na Devassa ou, então, em papéis correlatos como as que dão conta das averiguaçôes ordenadas por D. Fernando José de Portugal sobre a suposta francezia de Francisco Agostino Gomes ${ }^{23}$.

O confronto entre o constante da Devassa com as informações dispersas por documentação de outras origens resulta em consistente evidência de homens brancos e proprietários terem estado envolvidos em atividades sediciosas na Bahia de fins do século XVIII. Veja-se que para além dos que, portadores desses atributos, foram presos, julgados e condenados a penas variadas ${ }^{24}$, outros - aos quais não é cabível atribuir a condição de "classe média" - foram citados na Devassa, a exemplo de José Borges de Barros, Francisco Agostinho Gomes, João da Rocha Dantas. Este último era filho do desembargador conselheiro chanceler Antônio da Rocha Dantas, personagem importante na estrutura de poder. E nem foram poupados de incômodos Ignacio de Cerqueira Bulcão, grande proprietário e senhor de engenhos, ou Francisco Agostinho Gomes, homem de grande fortuna como é amplamente sabido.

Mas há desvios dessa norma: José Borges de Barros, citado várias vezes como integrante do círculo de relações íntimas de Raimundo Moniz Barreto de Aragão, o professor régio condenado, sequer foi arrolado como testemunha, tendo desaparecido aparentemente sem deixar vestígios, para 
ressurgir alguns anos mais tarde, na Europa, seja como tradutor de Thomas Payne para o português, como maçon e como falsário movido pela intenção de levantar fundos para o financiamento da revolução na Bahia ${ }^{25}$, de onde fugira às vésperas da instauração da Devassa, do mesmo modo como o fez João Ladislau no entremeio entre a divulgação dos pasquins e a prisão de Cipriano Barata ${ }^{26}$, um e outro temerosos de serem inculpados de prática sediciosa por motivos que, mais que ninguém, eles conheciam.

Os de Borges de Barros, João Ladislau, Gomes ou Cerqueira Bulcão são evidentes casos de homens bem instalados no interior da elite colonial da Bahia de fins dos setecentos. E ainda que faltem listas nominais dos participantes, é pertinente admitir que vários dentre eles tenham integrado o grupo de jovens baianos ${ }^{27}$ que conviveram com Antoine René Larcher quando de sua estada em Salvador ${ }^{28}$.

De resto, as cartas do oficial francês iluminam o significado de passagens até agora obscuras da Devassa, em especial as referentes à hipótese de auxílio externo para o projeto revolucionário mal e mal arquitetado na Bahia, em geral atribuídas pela historiografia a recursos de retórica política ou, simplesmente, a devaneios sem base na realidade. É o caso da referência, nos pasquins sediciosos, a que "logo teremos auxílio estrangeiro" 29 se "feita a (...) revolução nesta cidade e seu termo"30, e que para "aqui virão todos os estrangeiros tendo porto aberto, mormente a nação francesa" ${ }^{\text {" }}$. Ou então, da fugaz referência de Manuel dos Santos Lira, nos Autos da Devassa, a Cipriano Barata ter-lhe dito que dever-se-ia ser prudente na ação devido ao despreparo da "maior parte dos habitantes desse continente" para empreendimento do porte de uma revolução, sendo de melhor alvitre "esperar que viessem os franceses"32.

Deve ter sido tortuoso o caminho percorrido por esta informação - o possível auxílio francês - de seus idealizadores até Manuel dos Santos Lira ou Luís Gonzaga, figura paradigmática do pardo pobre politicamente radicalizado na Bahia de então, e provável autor dos papéis que desencadearam as ações repressivas. O que se pode dar por contado é que, malgrado a ínfima possibilidade de Larcher ter confraternizado com pessoas de nível social tão distinto do seu, tanto por limitaçôes de língua, de valores e por evidentes questôes de segurança, o teor dos entendimentos que manteve com seus interlocutores inseridos nos estratos superiores da sociedade lo- 
cal percorreu dutos de uma capilaridade política que conectava entre si homens que, de diferentes condições sociais, tinham em alto apreço as idéias vindas da França revolucionária.

O fato de alguém com o cargo e a importância do capitão Antoine René Larcher ter concordado em ser intermediário entre os conspiradores baianos e a República francesa (proclamada havia apenas quatro anos) e, mais do que isso, ter advogado e assumido a proposta, pode ser compreendido pelo contexto e pelos atores envolvidos, também, do lado francês, inclusive a não conseqüência, por parte do Diretório, de tais pretensões.

Aquele momento histórico marcava-se por dupla questão: de um lado, entusiasmo pela expansão militar da Revolução Francesa e vitórias obtidas contra adversários internos e internacionais; ao mesmo tempo, período delicado da política colonial e das relações exteriores, com a tendência expansionista se ampliando e após a abolição da escravidão nas colônias francesas em 1794. Em outras palavras, para utilizar expressão do conhecido estudo de Jacques Godechot ${ }^{33}$, era o momento em que se afirmava a perspectiva da Grande Nação, ou seja, da possibilidade de exportação dos ideais revolucionários e do poderio administrativo, militar, cultural, econômico e político da França. A construção desta Grande Nação se dava através de conflitos e tensões internas na própria nação francesa.

O ministro da Marinha e das Colônias a quem Larcher inicialmente endereçava suas cartas era o conde Laurent-Jean-François Truguet (17521839), nomeado por Lazare Carnot, principal nome do Diretório e chefe militar destacado neste período que marcou a ascensão do poderio bélico francês, que chegaria ao apogeu com Napoleão Bonaparte ${ }^{34}$. Truguet entrara para a Marinha Real francesa no quadro do Antigo Regime: participou da guerra de Independência dos Estados Unidos, promovido a contra-almirante em 1792, se aliou aos federalistas e girondinos franceses, sendo preso pelos jacobinos em 1793. Com a queda destes, acaba nomeado ministro da Marinha e das Colônias em novembro de 1795, cargo que exerce até 18 de julho de 1797, quando é afastado no quadro que geraria o golpe de Estado deste ano, que fortalece o Diretório e prende vários monarquistas. Truguet seria nomeado conselheiro por Napoleão Bonaparte 
em 1801, para quem comandaria as Esquadras francesas no Mediterrâneo e no Atlântico. Com a Restauração da monarquia na França, Truguet se aliaria ao governo de Luis XVIII. Ao sair do ministério da Marinha e das Colônias em 1797, Truguet foi sucedido por Georges René Pléville le Pelley, que ocuparia o cargo até abril de 1798; este posto seria exercido interinamente por Talleyrand em 1799.

O Diretório da República francesa no momento destas correspondências de Larcher era composto por: Lazare Carnot, Jean-François Reubell, Paul Barras, Louis-Marie de la Révellière-Lépaux e François de Barthélemy. Carnot e Barras eram as duas figuras preponderantes. Carnot foi dirigente militar de relevo, que esteve à frente de importantes vitórias militares francesas durante a Revolução, abrindo caminho para a expansão napoleônica, da qual, entretanto, não participaria diretamente, por desavenças. Oriundo dos montagnards, ala mais à esquerda na Revolução Francesa, Carnot se afastaria dela com a ascensão de Robespierre, servindo posteriormente a Napoleão, mas definitivamente banido da vida pública com a Restauração, falecendo no exílio ${ }^{35}$.

O Diretório efetuava uma política de tipo juste milieu que, se por um lado visava barrar o retorno das forças do Antigo Regime, por outro combatia os considerados "excessos" revolucionários, buscando estabilizar as conquistas revolucionárias, mas sem aprofundá-las. A própria Constituição vigente na França, desde setembro de 1795, da qual Larcher deixara um exemplar em Salvador, expressava esta situação: mantinha o governo republicano, mas eliminava alguns princípios revolucionários e sociais contidos na Constituição anterior, de 1793, elaborada pelos jacobinos, como os mecanismos de democracia e participação direta. A Constituição francesa divulgada na Bahia, pois, se baseava na repartição de poderes entre os membros do Executivo formado por um colegiado de cinco pessoas (o Diretório) e destes com o Legislativo formado por dois corpos, equivalentes à Câmara dos Deputados e ao Senado. Ela restabelecia o sufrágio censitário e indireto (em duas etapas), por rejeição ao voto universal.

Nota-se, pois, que os interlocutores de Larcher no governo francês tinham posições com matizes diversas, que resultariam em atitudes diferenciadas. Enquanto Carnot, do Diretório, era oriundo dos jacobinos e se incompatibilizaria com os monarquistas, Truguet, o ministro da Marinha, 
oriundo dos girondinos, futuramente serviria à Restauração monárquica. A expectativa que Larcher desenvolveu para a América portuguesa poderia encontrar eco em determinados setores e resistência em outros, mas, de qualquer modo, todos estavam limitados por questóes daquele contexto.

Naqueles anos de 1795-1799 a França experimentara importantes vitórias políticas ou militares (Holanda, Suíça e Itália) e assinara acordos de paz com Espanha e Prússia, o que poderia justificar o entusiasmo do capitão Larcher em buscar abrir tais caminhos nas Américas. Mas a campanha do Egito em 1798, como se sabe, quando Napoleão, apesar das conquistas que obteve, foi derrotado pela frota inglesa, assinalou naquele momento os limites geopolíticos da Grande Nação e sua dificuldade em se expandir fora do continente europeu. Os conflitos sociais também eram marcantes. Nos idos de 1797, Gracchus Babeuf foi executado em Paris, por tentar uma sublevação popular que implantasse um comunismo agrário. Mesmo período em que o liberto Toussaint Louverture conquista o cargo de Governador Geral e chefe das forças armadas em São Domingos, no Caribe francês, à frente de milhares de homens em armas, a maioria composta também de ex-escravos.

Uma questão que permeava o projeto para a Bahia apoiado por Larcher era a da escravidão. Embora o militar não tratasse desse ponto em suas correspondências às autoridades francesas (nem mesmo as manifestações conhecidas em 1798 na Bahia apontassem de forma consistente uma solução abolicionista), a grande insurreição dos escravos iniciada na colônia francesa de São Domingos em 1791 tornava a questão incontornável naquele momento. O próprio Larcher, como se sabe, fora portador, quando de sua passagem pelo Brasil em 1796, da notícia oficial da abolição da escravidão nas colônias francesas para as Ilhas Maurícias, ocasião em que foi expulso desta localidade pelos colonos franceses insatisfeitos com tal medida.

A abolição da escravidão pelos dirigentes da Revolução Francesa ocorrera após muita hesitação e contradiçõos entre os ideais de igualdade universal e os interesses comerciais e agrários de setores da sociedade francesa e fora resultado, sobretudo, dos acontecimentos de São Domingos, quando a longa e abrangente insurreição de escravos se transformou em movimento revolucionário que destruiu o escravismo na prática, eliminando posteriormente a dominação colonial francesa. Entretanto, como resulta- 
do destas tensões internas, Napoleão, em 1802, restabeleceria a escravidão nas colônias francesas, menos em São Domingos, onde ela fora exterminada à força ${ }^{36}$.

As tentativas do capitão Larcher eram simultâneas a outras iniciativas de negociação, pela via diplomática, nas quais a França tentava obter parcelas do território brasileiro. Foi o caso envolvendo o fidalgo ilustrado Antonio de Araújo de Azevedo (1754-1817), futuro conde da Barca (receberia o título em 1815), que apresentava rivalidade com D. Rodrigo de Sousa Coutinho (futuro conde de Linhares). Ambos situavam-se no interior da Coroa portuguesa como expoentes dos "partidos" francês e inglês, respectivamente. Ou seja, no bojo da crise da Revolução Francesa e posterior invasão da península ibérica pelos franceses, ambos tomaram posições antagônicas no alinhamento às duas potências européias. Com o reforço e aumento da proeminência britânica sobre Portugal, D. Rodrigo saiu-se melhor. Talvez o pior incidente entre ambos tenha ocorrido justamente em 1797, quando Araújo de Azevedo foi enviado a Paris pelo governo português para negociar um tratado com o governo do Diretório. O acordo fechado por ele previa, entre outros aspectos, ceder parte da Amazônia brasileira à França. Ao chegar a notícia deste tratado em Portugal, D. Rodrigo, que acabara de ascender ao ministério, conseguiu vetá-lo e o resultado é que as autoridades revolucionárias francesas, insatisfeitas com o recuo, prenderam Araújo de Azevedo por alguns meses ${ }^{37}$.

Mais especificamente no caso brasileiro, o século XVIII já apresentara tentativas concretas e malogradas de ocupação militar francesa, como no Rio de Janeiro em 1710, além dos corsários e contrabandos constantes por todo o litoral. Só em 1794, por exemplo, foram sete navios luso-brasileiros oriundos da Bahia apreendidos pela esquadra francesa em torno da costa africana ${ }^{38}$. Destacando-se, ainda, a tentativa de desembarque no litoral do Sul da Bahia de uma nau e um brigue franceses com 200 homens em 1796, rechaçada pelos moradores locais ${ }^{39}$.

O Projeto de invasão da Bahia redigido por Larcher, pois, não era fruto de rompante ou delírio revolucionário, mas uma tentativa que, embora ousada, surgia em determinado contexto. E nem foi unilateral, mas calcado na demanda de setores da sociedade local. Deste modo se compreende como o capitão Larcher, ocupando o importante cargo de Chefe 
de Divisão das Armadas Navais Francesas, tenha vislumbrado e tentado efetivar a extensão desta Grande Nação revolucionária à Bahia, onde ele chegara por lances imprevistos e encontrara acolhida em variados grupos e pessoas. Caso o projeto fosse bem sucedido, Larcher seria figura destacada na nova situação a ser implementada nas relações entre Bahia e a França, que teriam efeitos pelo resto do Brasil e trariam conseqüências comerciais e políticas palpáveis. Por outro lado, poderiam trazer a guerra diretamente para o continente americano e colocariam alguns milhares de fuzis nas mãos de homens das camadas pobres. Por isso é possível compreender também os obstáculos geopolíticos, militares e sociais que abortaram este projeto do lado francês.

A viagem do capitão Larcher durou quase dois anos, repleta de lances perigosos, desde sua partida da França em setembro de 1795 ao retorno em junho ou julho de 1797. A passagem pela Bahia, embora imprevista, representou um episódio que se encadeava com os demais. Ainda que fuja ao objetivo deste trabalho situar o roteiro do trajeto, vale destacar alguns pontos que interessam ao caso aqui tratado.

Comandante da fragata La Preneuse, em dezembro de 1795 Larcher chefiou o bem sucedido ataque ao navio luso-brasileiro Santo Antonio de Polifemo, comandado por Manoel do Nascimento da Costa, que fazia o Comercio com a Índia. No combate de quatro horas e meia foram mortos oito homens do lado luso-brasileiro: cinco soldados, um marinheiro, o tenente João Cordeiro do Vale e frei Agostinho de Newfonte, além de seis feridos, entre os quais Antonio José de Almeida, secretário de Estado de Goa que se encontrava a bordo. O carregamento confiscado pelos militares franceses se constituía de açúcar, aguardente, tabaco, ferro e fardamento para as tropas portuguesas na Ásia. Passada a violenta refrega e feita a presa, inclusive do armamento e munição, Larcher negociou de maneira cortês com o capitão derrotado, redigindo-lhe um salvo-conduto destinado aos demais navios franceses, solicitando que não atacassem mais e embarcação, o que permitiu ao Santo Antonio de Polifemo regressar à Bahia sem ser mais molestado e com os sobreviventes em liberdade ${ }^{40}$. Tal atitude 
de negociação ajuda a entender como Larcher, alguns meses depois, seria bem recebido em Salvador, onde aportou em novembro de 1796, agora como simples passageiro do navio luso-brasileiro Boa Viagem, oriundo da Ásia, de onde saíra sem sua embarcação La Preneuse, expulso pelos colonos franceses escravocratas, como já foi citado ${ }^{41}$.

Foi então, durante estada de cerca de um mês em Salvador, que ocorreram os contatos do capitão Larcher com as mais altas autoridades, como o próprio capitão general D. Fernando José de Portugal, e também com os conspiradores locais, geradores das duas cartas aqui transcritas, episódio que já mereceu interpretações diversificadas de historiadores ao longo do tempo, como já foi visto. E foi ainda num navio português, Bom Jesus, que Larcher retornou à Europa em janeiro de 1797, ficando retido, a contragosto, na capital portuguesa, sem recursos para retornar a seu país natal.

Enquanto aguardava em Lisboa, pelo menos entre março e junho de 1797, o capitão Larcher parecia ansioso em levar adiante o projetado apoio francês aos conspiradores baianos. A estada de Larcher na capital portuguesa foi penosa e tensa devido aos desdobramentos da crise européia causada pela Revolução Francesa e suas conseqüências, como se pode depreender de três outras cartas que escreveu a seus superiores ${ }^{42}$. Por um lado, Larcher se via na incômoda posição de ficar em Lisboa ao sabor de negociações (recheadas de rumores alarmistas) entre as potências e sob a vigilância do governo português, de quem recebeu inclusive proposta para se alinhar ${ }^{43}$. Por outro, manteve-se fiel ao governo de seu país e suas cartas beiravam a atividade de espionagem: chegou a informar detalhadamente ao Diretório sobre as movimentações das embarcações e tropas inglesas, portuguesas e dos emigrados franceses em Portugal, apesar do pedido formal que recebeu das autoridades portuguesas para não tocar no assunto com o governo da França revolucionária ${ }^{44}$. Até escapou a Larcher um comentário maledicente quanto à capacidade militar dos soldados do Brasil que teriam sido chamados para apoiar a guerra na Europa, ao afirmar que, se fossem iguais aos baianos, não havia o que temer deles ${ }^{45}$. Enquanto o futuro conde da Barca negociava, em Paris, tratados com o Diretório que nunca seriam cumpridos, Larcher ficava em Lisboa à mercê dos acontecimentos, sem receber resposta da França e, sobretudo, sem dinheiro para 
suas despesas e viagem de volta. Chegou a solicitar formalmente ao governo português esta verba em forma de empréstimo, pedido negado ${ }^{46}$.

Vê-se assim que o perfil de Larcher emerge desta situação não como o de um aventureiro ou mercenário de guerra, tão comum naqueles tempos, nem como um dúbio oficial aristocrata, ou tresloucado revolucionário desgarrado, mas o de um militar profissional identificado aos projetos expansionistas de seu próprio país. Dificilmente gastaria tempo, tinta de escrever e colocaria seu prestígio pessoal em jogo se não tivesse sido concretamente convencido e incentivado pelos contatos que fez na Bahia a levar adiante o pedido de apoio ao intentado levante.

O Projeto transcrito a seguir, datado de 24 de abril de 1797 e enviado de Lisboa a Paris, é em certa medida auto-explicativo, pelo menos no tocante aos planos de invasão, isto é, no que os conspiradores baianos pediam à República Francesa e prometiam a esta em contrapartida, através do capitão Larcher. Em linhas gerais, tratava-se de apoio militar para proclamar a Independência da Bahia em troca de privilegiados acordos comerciais.

Nota-se neste mesmo Projeto a expectativa de que todo o território brasileiro pudesse, a partir dos eventos da Bahia, proclamar também a Independência de forma unificada, ao afirmar que "as outras capitanias do Brasil" formariam "um povo livre". Resta saber se tal enunciado escrito por Larcher era fruto apenas de sua percepção individual ou se foi colhido por ele dos conspiradores baianos. Nem se sabe, também, se tal perspectiva "brasileira" era embasada em contatos prévios com outras capitanias ou mera especulação, enfim, um cenário visto como possível. Mas, de qualquer modo se configura, em tal testemunho referente a 1796, uma das primeiras manifestações explícitas quanto à possibilidade de as diversas capitanias brasileiras proclamarem de forma unificada a Independência de Portugal, da parte de protagonistas favoráveis a tal medida. Nos Autos das Devassas de 1798, aliás, aparece de forma constante, mas inconsistente quanto às provas, esta acusação de que os conspiradores baianos queriam sublevar todo o "continente do Brasil".

Outro ponto a ser assinalado é que a França, pelo menos nas palavras do capitão Larcher, pretendia exercer um exclusivo comercial junto ao Brasil, em substituição ao que era exercido de Portugal, aspecto que apare- 
ce nos dois documentos aqui transcritos, como se verá a seguir. Apesar da conjuntura revolucionária, tratava-se da manutenção de antigas práticas monopolistas, ambivalência, aliás, que seria mantida pela França na mesma ocasião em outros locais, como na colônia caribenha de São Domingos, por exemplo, configurando o paradoxo da Revolução Francesa diante do que passava a ser considerado como "problema colonial" 47 . Do mesmo modo, o militar francês reiterou, nos dois textos aqui transcritos, que tratou destes assuntos de conspiração com setores das elites baianas.

Já a carta escrita também de Lisboa para o Diretório da República Francesa sobre o mesmo tema e datada de 15 de junho de 1797 (quase dois meses após o Projeto e também transcrita a seguir) traz algumas características interessantes. Por medida de precaução (temia-se que a correspondência fosse interceptada no trajeto entre Portugal e Paris, como afirma o próprio Larcher) não há referência explícita ao local da conspiração, embora seus termos e a data não deixem dúvidas que se tratava do mesmo caso da Bahia. A iniciativa desta nova mensagem resulta de um misto de reforço e insistência com a proposta, ao lado do temor de que a correspondência anterior tivesse se extraviado e, embora mais sutilmente, o receio de que o próprio ministro da Marinha e das Colônias, Truguet, identificado com ala moderada, girondina e até monarquista de Revolução, tivesse engavetado o assunto ${ }^{48}$. Além do mais, Larcher parecia ter motivos de sobra para sua desconfiança, pois encontrava-se abandonado em Lisboa, sem apoio momentâneo das autoridades francesas, como foi visto.

Ao mesmo tempo, Larcher inclui nesta segunda missiva detalhes que sugerem como a conspiração baiana estava avançada ("O Plano está feito e adotado"), inclusive no tocante à possibilidade da intervenção militar francesa. Informa que havia dois homens (aos quais não nomeia) entre os conspiradores dispostos a irem até a França para negociarem pessoalmente e que até os sinais (convençôes) para comunicação entre os conspiradores já estavam definidos. Especifica algumas das ocupações dos envolvidos ("pessoas instruídas", negociantes e militares), evidenciando que seus contatos realizavam-se entre setores das elites locais, como era aliás mais plausível, o que remete para a abrangência social dos conspiradores, que não se limitavam, portanto, às camadas pobres ou médias da população. 
Quanto ao papel a ser exercido pela França na Bahia, nesta nova situação projetada, destaca-se sintomaticamente na pretensão francesa, expressa por Larcher, a efetivação de um exclusivo comercial francês em substituição ao português, ainda que por prazo a ser determinado. Vê-se que a perspectiva revolucionária francesa não acompanhava as propaladas "novas idéias" nas relações econômicas.

Temos, nestes dois documentos produzidos por Larcher, elementos sugestivos para acrescentar outros traços ao conhecimento da Conjuração Baiana, que foge assim da caracterização de ser vista apenas como um episódio de âmbito regional e conduzida pela plebe com viés de insatisfação por motivos étnicos e sociais. Pelo menos enquanto perspectiva, colocou-se a possibilidade de inserção e articulação da capitania da Bahia em novos tempos da América portuguesa e da Europa, ou seja, na Era das Revoluções. Está claro que setores pobres e mais mobilizados da população baiana (ainda que minoritários no conjunto da sociedade e talvez até no interior da conspiração) assumiram e reinterpretaram a seu modo não só os ideais de liberdade, igualdade e fraternidade, como também a informação sobre as articulações efetivadas com uma autoridade da República francesa. Mas estas, como foi visto, foram realizadas, ao que tudo indica, com membros das elites baianas, que acabaram ficando fora do quadro repressivo montado pelas autoridades portuguesas na Bahia e mesmo de parte da compreensão historiográfica.

1) Projeto de invasão da Bahia pelas tropas da Revolução Francesa

\section{1 - Tradução para o português}

[p.1]

América Meridional

Brasil

Projeto de expedição contra São Salvador (Brasil) pelo Cap. de navio Larcher - 24 de abril de 1797

[p.2]

Cópia da memória que eu enderecei ao Diretório Executivo ${ }^{49}$ de Madri a 7 frutidor $^{50}$ do $5^{\circ}$ 
O Povo, que eu tive a honra de Vos descrever na minha memória de 27 Prairéal $^{52} 5^{\circ}$, é aquele de São Salvador na Baía de Todos os Santos, capital da mais considerável Capitania do Brasil cuja População é avaliada em sessenta mil almas.

Os habitantes investidos dos direitos do homem clamam sua independência; eles a pedem à República francesa, e não a Desejam senão de Vós.

Quinze Milhões no mínimo em matérias de ouro e prata, diamantes, preciosas madeiras de construção, açúcares, café, e algodões serão o testemunho desta Vontade, e Vós podeis julgar por aí a importância que eles dão a isso: eles estão tão cansados do Governo real e teocrático, tiveram tantos desgostos que todos os seus possíveis sacrifícios lhes parecerão pequenos, se eles puderem alcançar seu objetivo.

Os meios de execução são fáceis e pouco dispendiosos: 4 Navios de linha, 3 fragatas, e 2 flûtes $^{53}$ serão suficientes para transportar 1500 homens de tropas e 300 artilheiros.

4000 fuzis com suas baionetas, o mesmo de sabres, de pólvora (o Governo não permite que se fabrique) e balas de canhão de diferentes calibres: eis suas necessidades do momento: eles desejam um engenheiro, um arquiteto, um ferreiro e um mecânico: estes são os pedidos que eu fui incumbido de Vos fazer em nome deles.

Esta Divisão poderá atracar na Baía de Todos os Santos à porta dos fortes, eles não são perigosos; não havia mais de $700 \mathrm{~kg}$ de Pólvora na minha partida, e o Governo temia enviar-lhes mais, tanto as cabeças estão em efervescência.

[p.3]

Assim que o comandante da divisão tiver lançado o sinal combinado, a colônia se levantará em massa, as tropas se reunirão aos habitantes que tomarão a casa da moeda, cofres, depósitos, e o arsenal: destituem-se todas as autoridades do Governo, e criam-se outras Populares: uma deputação de Cidadãos irá a bordo do comandante para lhe pedir a proteção da República francesa; Vós lhe direis o veredicto que ele deverá dar: se esta revolução se opera, como ela está projetada, ela só sentirá o fogo das manifestaçôes de júbilo.

Esta revolução terá um efeito elétrico sobre as outras capitanias do Brasil, a experiência nos prova: todas elas se reunirão para formar um povo livre. 
Vantagens para o Comercio da República francesa que o estado de suas colônias torna ainda mais precioso.

Um tratado de aliança com a República francesa terá lugar imediatamente: um outro de Comercio deve necessariamente o seguir: a República francesa poderá exigir a exclusividade durante um certo número de anos em que sua proteção será indispensável a este novo Povo, quer dizer, até que ele tenha determinado a forma de seu Governo o tenha organizado, consolidado, e feito reconhecer sua independência: esta expedição, que exige o maior segredo, pode ser dissimulada; ela pode mesmo ter uma dupla utilidade do maior interesse.

Há muitas vezes contra os planos mais bem arquitetados objeções que escapam ao olho mais experiente: Do grande teatro Político que ocupeis , Vos será fácil, cidadãos Diretores, calcular as grandes vantagens que esta revolução proporcionará ao Comercio da república francesa, o abatimento que poderá resultar para este nosso inimigo, assim como os inconvenientes que uma consideração política poderia levantar.

[p.4]

Se eu pudesse ter partido para França, no mesmo instante de minha chegada a Lisboa, e Vós tivésseis querido secundar às Vozes deste Povo, esta Revolução seria operada, e Vós não tardaríeis a gozar as vantagens prometidas.

Cidadãos Diretores, Órgão deste Povo, eu cumpro a missão da qual fui encarregado por ele junto a Vós, Eu faço meu dever, e posso vos assegurar que a paz não mudará em nada a determinação que ele tomou de ser livre.

Assinado Larcher Cap. de Navio.

\section{2 - Original em francês:}

[p.1]

Amérique Méridionale

Brésil

Projet d'expedition contre San Salvador (Brésil) par le Cap. de Vau Larcher -24 avril 1797

[p.2]

Copie du mémoire que j'ai adressé au Directoire Exécutif de Madrid Le 7 frutidor au $5^{\grave{e}}$ 
Le Peuple, que jai eu l'honneur de Vous désigner dans mon mémoire du 27 Prairéal 5è, est celui de San Salvador dans la baie de tous les saints, capitale de la Capitainerie la plus considérable du Brésil dont la Population est évalueé à soixante mille ames.

Les habitants pénétrés des droits de l'homme Réclament leur indépendance; ils la demandent à la République française, et ne Veulent la tenir que de Vous.

Quinze Millions au moins en matieres d'or et d'argent, des diamants, des bois précieux de construction, des sucres, du caffé, et des cotons seront le témoignage, et Vous pouvés juger par là de l'importance qu'il y attachent: ils sons si fatigués du Gouvernement roial et théocratique, ils l'ont tellement eu éxécrations que tous ses sacrifices possibles leurs paraitront légers, sills peuvent parvenir à ce but.

Les moiens d'éxécution sont faciles et peu dispendieux: 4 Vaisseaux de ligne, 3 frégates, et 2 flutes suffiront pour transporter 1500 hommes de troupes et 300 artilleurs.

4000 fusils avec leurs baionnetes, autant de sabres, de la poudre (le Gouvernemnet ne leur permet pas d'en faire) et des boulets de différents calibres: Voilà leurs bésoins du moment: ils désirent um ingénieur, un architecte, un fondeur et un mécanicien: telles sons les demandes que je suis chargé de Vous faire en leur nom.

Cette Division pourra mouiller dans la Baie de tous les saints à la porte des forts, ils ne sont pas dangéreux; il n'y avait pas plus de $700 \mathrm{~kg}$ de Poudre à mon départ, et le Gouvernement craignait d'y en envoier[sic], tant les têtes sont en effervescence.

[p.3]

Dès que le commandant de la division aura laissé le signal convenu, la colonie se leve en masse, les troupes ses réunissent aux habitants qui semparens de la monaire, des caisses, des magazins[sic], et de l'arcenal: on destitue toutes les autorités du Governement, et on en crée de Populaires: une députation de Citoyens se rendra à bord du commandant pour demander la protection de la République française; Vous lui dicterés la réponse qu'il devra faire: si cette révolution s'opere, comme elle est projetté, il ne sera pas brulé d'autres annonces que celle de réjouissance.

Cette révolution aura un effet électrique sur les autres capitaineries du Brésil; l'expérience nous le prouve: elles se réuniront toutes pour former un peuple libre. 
Um traité d'alliance avec la République française aura lieu sur le champ: un autre de commerce doit nécessairement s'en suivre: la République française pourra éxiger l'exclusif pendant un certain nombre d'anneés que sa protection sera indispensable à ce nouveau Peuple, C'est a dire, jusquà ce qu'il ait détermineé la forme de son Governement l'ait organisé, consolidé, et fait reconnaitre son indépendence: cette expédition, qui exige le plus grand secret, peut être masqueé; elle peut même avoir une double utilité du plus grand intérêt.

Il est souvent contre les plans les mieux combinés des objections qui échappent à l'ocil le plus éxercé: Placés sur le grand théatre Politique, il Vous sera facile, citoyens Directeurs, de calculer les grands avantages que cette révolution procurerait au commerce de la république française, l'affaiblissement qui pourrait en résulter pour celui de nos ennemis, ainsi que les inconvénients dont des considérations politiques pourraient être la base.

[p.4]

Si j’avais pu partir pour france, aussitôt mon arriveé à Lisbonne(a), et que Vous aimés Voulu seconder les Voeux de ce Peuple, cette Révolution serait opéreé, et Vous ne tarderiés pas a jouir des avantages promis.

Citoyens Directeurs, Organe de ce Peuple, je remplis la mission dont il má chargé auprès de Vous, Je fais mon devoir, et je puis Vous assurer que la paix ne changera rien à la détermination qu'il a prise d'être livre.

Signé Larcher Cap. de Viu

\section{2) Carta ao Diretório da República Francesa}

2.1- Tradução em português:

15 de Junho de 1797

Ao Diretório Executivo da República Francesa somente,

Cidadãos Diretores ${ }^{54}$,

Eu acreditaria estar em falta ao que devo ao Ministro da Marinha e das Colônias se eu tomasse a Liberdade de Vos ocupar do caso sobre o qual ele certamente já Vos relatou.

Um interesse maior me obriga a romper neste momento o silêncio que eu guardava há mais de dois meses, desde que estou aqui na Esperança de um imediato retorno para a França; mas devo supor que minhas Cartas ao Ministro da Marinha foram interceptadas, pois estou sem resposta. 
Um Povo, aterrado pelo duplo Despotismo da Monarquia e da teocracia, Vos implora por Lhe dar A Liberdade. Ele quer adotar a Constituição atual da República Francesa, da qual eu pude felizmente Lhe dar um Exemplar ${ }^{55}$; Ele me escolheu para ser seu órgão junto a Vós; Pessoas instruídas, negociantes, militares esperam de Vós esta Benemerência; Dois dentre eles estão prontos a irem ao Vosso encontro assim que chamados; não Lhes custará nenhum sacrifício; O Plano está feito e adotado; Eles até já me deram os sinais de Convenção. Enfim, o desespero está tão perto de suas almas que, se eles estão há um ano, a contar de minha Partida, sem receber nenhuma Esperança, deve-se esperar a Ver este povo chegar a algum extremismo que poderia ser funesto, se ele fica abandonado a si mesmo. Vós julgareis na Vossa Sabedoria, Cidadãos Diretores, se a proposta da qual sou encarregado de Vos encaminhar é de fácil execução; permitam que eu aguarde meu retorno à França para entrar em esclarecimentos mais aprofundados; tudo que posso assegurar-lhes é que Nada no Mundo não pode vir a ser tão útil à prosperidade da República francesa, sobretudo estando obrigada apenas a reduzidas iniciativas.

Eu aqui estou livre; estou deslocado em todos os sentidos, sobretudo após a perda que causei ao Estado e ao Comercio pelo aprisionamento que fiz da fragata portuguesa $O$ Polifemo após um combate de quatro horas e meia. O ministro da Marinha e das Colônias Vos terá sem dúvida feito ver as Razões que me retêm aqui.

O Chefe da Divisão das Armadas Navais da República Francesa, Larcher.

2.2 - Original em francês:

[fl.1]

15 Juin

1797

Au Directoire Exécutif de La République française Seul

\section{Citoyens Directeurs}

Je croirois[sic] manquee à ce que Je dois au Ministre de la Marine et des Colonies, si je prenois[sic] La Liberté de Vous entretenir de mon affaire de laquelle Il a vu déja Vous rendre compte. 
Un plus grand Interêt m'obllige a rompre dans ce momént Le silence que je gardois[sic] depuis plus de deux mois que je suis ici dans L'Espérance d'un prompt retour en france; mais je dois présumer que mês Lettres au Ministre de la marine ont été intercepteés, puis que je suis sans Réponse.

Un Peuple, terrassé par le double [fl.1v.] Despotisme de La Monarchie et de La théocratie, Vous implore pour Lui donner La Liberté; Il Veut adopter La Constitution actuelle de La République française dont j'ai pu heuresement Lui donner un Exemplaire; Il m'a choisi pour être Son organe auprès de Vous; Gens instruits négotiants[sic], militaires attendent de Vous ce Bienfait; Deux d'entre eux sont prêts a se Rendre auprès de Vous au premier ordre; aucun sacrifice ne Leur Coutera; Le Plan est fait et adopté; Ils m'ont même donné les signaux de Convention. Enfin le déséspoir est si prés de leur ame[?] que, s'ils sont un an, a compter de mon Départ, sans Recevoir aucune Espérance on doit l'attendre a Voir Ce peuple se porter à quelque extremité qui pourroit[sic] être funeste, s'il est abandonné à lui même. Vous Jugerés dans Votre Sagesse, Citoyens Directeurs, si L'expédition que Je suis chargé de Vous proposer est de facile exécutions; Permettés que je Remetre à [fl.2] mon Retour en france pour entrer dans des plus amples éclaircissemens; tout ce dont je puis Vous assures, C'est que Rien au Monde ne peut parvitre[?] aussi utile à La prospérité de la République française, surtout n'étant obligé qu'à de faibles moiens.

Je suis libre ici; J'y suis déplacé sous tous Les raports, surtout d'après La perte j'ai causeé à L 'Etat, et au commerce par La prise que j'ai faitte[sic] de la frégate Portugaise Le Poliphême aprés um engagement de 4 heures 3/4: Le ministre de la Marine et des Colonies Vous aura sans doutte mis sous les yeux les Raisons qui me Retiement ici.

Le Chef de division des armeés navales de La République française.

Larcher

Lisbonne

27 Prairéal au $5^{\text {eme }}$

\section{Notas}

${ }^{1}$ A referência dos documentos é a seguinte: Série BB4, 1050, Archives de la Marine, Paris. Este Projeto de invasão francesa na Bahia foi citado inicialmente por J. Potelet, Projets d'expédition et d'attaques sur les cotes du Brésil (1796 - 1800), Caravelle Cahiers du monde hispanique et luso-brésilien, Toulouse, n. 54, p. 212 seg., 1990; de- 
pois por M. Morel, Tensões entre revolução e escravismo: o caso de Cipriano Barata em 1798, em U. de Castro Araújo (org.), II Centenário da sedição de 1798 na Bahia , Salvador, 1999 e, também, analisado por JANCSÓ , I. Bahia 1798 - a hipótese do auxílio francês ou a cor dos gatos. In: Junia Furtado. (org) Diálogos Oceânicos - Minas Gerais e as novas abordagens para uma história do Império Ultramarino Português, Belo Horizonte: UFMG, 2001, pp.361-387.

${ }^{2}$ Agradecemos a Frédéric Pili a gentileza da cópia em microfilme dos originais, e a Andréa Slemian a transcrição dos dois documentos (e tradução e notas ao primeiro).

3 VILHENA, Luis dos Santos. Notícias soteropolitanas e brasílicas, Salvador: Imp. Of. do Estado, 1922.

${ }^{4}$ Arquivo do Instituto Histórico e Geográfico Brasileiro (AIHGB), L. 399

${ }^{5}$ ARMITAGE, J. História do Brasil. Belo Horizonte/São Paulo: 1981.

${ }^{6}$ VARNHAGEN, Francisco A. de. História Geral do Brasil. Belo Horizonte/São Paulo: vol. III, t.V, pp.24-5

${ }^{7}$ A respeito vide, de JANCSÓ, István. Um problema historiográfico: o legado de D. Fernando José de Portugal. Anais do IV Congresso de História da Bahia. Salvador: Instituto Geográfico e Histórico da Bahia / Fundação Gregório de Mattos, 2001, vol.I., pp.297322; Adendo à discussão da abrangência social da Inconfidência Bahiana de 1798. In: BLAJ, Ilana e MONTEIRO, John. (org) História e Utopias. São Paulo: ANPUH, 1996 (Anais do XVIIo Simpósio Nacional de História), e Na Bahia, contra o Império - História do ensaio de sedição de 1798. São Paulo: Hucitec, 1996.

${ }^{8}$ SILVA, Accioli de Cerqueira. Memórias históricas e politicas da Província da Bahia. Salvador: Imp. Of. do Estado, 1931, 6 v. (1 ( $^{\text {e }}$ ed. 1835-1852), vol. III, p.17 com preciosas anotações de Braz do Amaral.

${ }^{9} \mathrm{O}$ essencial do que pensava Francisco Borges de Barros sobre o tema está em Os Confederados do Partido da Liberdade. Salvador, 1922, mas também é útil consultar Sobre a conspiração de 1798 na Bahia (Anais do Arquivo Público da Bahia - AAPB) n.2, 1917; Primordios das sociedades secretas na Bahia (AAPB, n.15, 1926), e $A$ bandeira da revolução de 1798, (AAPB, n.9, 1922).

${ }^{10}$ De AMARAL Braz do vejam-se as suas anotações à obra de ACCIOLI I., op.cit, vol.III, além de $A$ conspiração republicana da Babia de 1798. Rio de Janeiro: Imp. Nacional, 1926 (Conferencia realizada no IHGB a 26.06.1926).

${ }^{11}$ RUY, Afonso. A primeira revolução social brasileira (1798). 2 $2^{\text {a }}$ ed. São Paulo, 1978 (Brasiliana vol.217).

12 Idem, p.4.

${ }^{13}$ Idem, p.38.

${ }^{14}$ Idem, p.122. Essa proposição de G. Barroso fez escola, cf. se pode ver em CASCUDO, Luiz da Câmara. O Doutor Barata - político, democrata e jornalista. Bahia: Imprensa Oficial do Estado, 1938.

${ }^{15}$ Se devem a ele: As idéias dos revolucionários de 1798, in: Arquivos da Universidade da Bahia. Salvador, Faculdade de Filosofia, 1955, n.4; Introdução ao estudo das idéias do 
movimento revolucionário de 1789. Salvador, 1959; Fontes teóricas do movimento revolucionário de 1798. Revista do Instituto Geográfico e Histórico da Bahia, n.80, 1956, Salvador; O movimento revolucionário baiano de 1798. Salvador, Universidade da Bahia 1960 (tese de livre docência); História da sedição intentada na Bahia em 1798 (a conspiração dos alfaiates). São Paulo, 1975; Cipriano Barata de Almeida. Revista do Instituto Histórico e Geográfico Brasileiro, v.347, 1985, Rio de Janeiro; Escravos no 1798. Anais da XI Reuniāo da SBPH. São Paulo, 1991; O desconhecido Francisco Agostinho Gomes. Anais da XIII Reunião da SBPH, Florianópolis, 1993; Jantar de carne em Sexta-feira Santa. Anais da XIV Reunião da SBPH, Salvador, 1994; Questōes ainda não resolvidas na história da sedição de 1798 na Bahia. II Centenário da Sedição de 1798 na Bahia, Salvador/Brasília, Academia de Letras da Bahia/MINC, 1999; O soldado Luis Gonzaga das Virgens. Estudos Avançados, USP, vol.13, n.37, set-dez.1999, São Paulo. O autor reuniu seus principais trabalhos recentes sobre 1798 no livro Da Sedição de 1798 à Revolta de 1824 na Bahia. Salvador / São Paulo: EDUFBA / UNESP, 2003.

16 TAVARES, História da sedição intentada na Bahia em 1798, p.95.

${ }^{17}$ Idem, p.96.

${ }^{18}$ A documentação relativa à Devassa mereceu várias ediçôes. Autos da Devassa da Conspiração dos Alfaiates, 2 vol., Salvador, Arquivo Público do Estado da Bahia, 1998 reuniu mediante criteriosa revisão crítica, o que estava disperso em A Inconfidência da Bahia: devassas e seqüestros, 2 vol., Rio de Janeiro, Officinas Graphicas da Bibliotheca Nacional, 1931, e em Anais do Arquivo Público da Bahia vol 35 e 36: Autos da Devassa do Levantamento e Sedição Intentados na Bahia, Salvador, Imprensa Oficial da Bahia, 1959 e 1961.

${ }^{19}$ Malgrado variações de ênfase, essa é a matriz explicativa básica que informa os estudos recentes dedicados aos eventos baianos do final dos oitocentos de MATTOSO, Kátia. Bahia 1798: os Panfletos revolucionários. Proposta de uma nova leitura. In: COGGIOLA, Osvaldo. (org) A Revolução francesa e seu impacto na América Latina. São Paulo/Brasília: EDUSP/Nova Stella/CNPq, 1990 (Simpósio Internacional “A Revolução francesa e seu Impacto na América Latina, São Paulo, jun.1989); de MAXWELL, Kenneth. A conspiração baiana de 1798. Folha de S. Paulo, Caderno Mais!, 26.07.98, Caderno 5º, p.6-7; de SILVA, Maria Beatriz Nizza da. Conflitos raciais e sociais na sedição de 1798 na Bahia. In: II Centenário da Sedição de 1798 na Bahia. Salvador/Brasília: Academia de Letras da Bahia/MINC, 1999, p. 37 seg; de ARAÚJO, Ubiratan Castro de. Ubiratan Castro de Araújo - A Bahia no tempo dos alfaiates. In: II Centenário da sedição de 1798 na Bahia, p.7 seg; de NEVES, Guilherme Pereira das. Bahia 1798: uma leitura colonial da Revolução Francesa. Acervo v.4, n.1, pp.121-4, Rio de Janeiro, 1989; De 1789 a 1798: percursos da francesia na Bahia. Revista da SBPH, p.18, Curitiba, 2000, pp.93-101, e ainda que indiretamente: A biblioteca de Francisco Agostinho Gomes: a permanência na ilustração luso-brasileira entre Portugal e o Brasil. Revista do IHGB, n.425, Rio de Janeiro, 2004, pp.11-27.

${ }^{20}$ Em especial Kenneth Maxwell e Valentim Alexandre.

${ }^{21}$ Op.cit. p.348. Cumpre registrar que a primeira notícia sobre os "documentos Larcher" devem-se a Kátia Mattoso, que deles deu notícia a Luis Henrique Dias Tavares, cf. JANCSÓ, István. Um problema Historiográfico: o legado de D. Fernando José de Por- 
tugal. Anais do IV Congresso de História da Bahia. Salvador: Instituto Geográfico e Histórico da Bahia / Fundação Gregório de Mattos, 2001, vol.1, pp.297-322.

22 SILVA, Evaristo L.I. Recordaçôes biographicas do Coronel João Ladisláu de Figueiredo e Mello ordenadas por seu neto Evaristo Ladisláu I. Silva, Bahia: Typ. de C. de L. Masson \& Cia., 1866. ${ }^{23}$ Esses papéis foram publicados por Braz do Amaral, em ACCIOLI - op.cit., pp.140-150. ${ }^{24}$ Neste grupo, estão os tenentes Hermógenes Francisco de Aguilar Pantoja e José Gomes de Oliveira Borges (condenados a um ano de prisão), o professor de gramática latina Francisco Moniz Barreto de Aragão, condenado ao açoite e degredo, pena reduzida finalmente, para "um ano de prisão tão somente na cadeia pública desta cidade e na privação da cadeira que tem excercido", ou José Raimundo Barata, irmão de Cipriano Barata, comerciante, condenado ao degredo, por três anos, na ilha de Fernando de Noronha. O próprio Cipriano Barata foi preso, interrogado, finalmente absolvido, ainda que somente libertado em 1800. Entre os que fugiram e, por isso mesmo, foram condenados à revelia, está Pedro Leão de Aguilar Pantoja - irmão do tenente Hermógenes.

${ }^{25}$ A esse respeito vide Bahia 1798 - a hipótese do auxílio francês ou a cor dos gatos. In: FURTADO, Junia. (org) Diálogos Oceânicos - Minas Gerais e as novas abordagens para uma história do Império Ultramarino Português. Belo Horizonte: UFMG, 2001, pp.361-387.

${ }^{26}$ Cf. SILVA, Evaristo L.I. - op.cit., p.4.

${ }^{27}$ Sobre a composição etária dos envolvidos no ensaio de sedição vide, de JANCSÓ, István. A sedução da liberdade: cotidiano e contestação política no final do Século XVIII. In: SOUZA, Laura de Melo (org) e NOVAIS, Fernando A. (dir) História da Vida Privada no Brasil - Cotidiano e Vida Privada na América Portuguesa. São Paulo, Cia. das Letras, 1997.

${ }^{28}$ A esse respeito, vide JANCSÓ, István. Contrabandos e idéias. In: DOMINGUES, C.V., LEMOS, C.V. e YGLESIAS, E. (org) Animai-vos, povo bahiense - A conspiração dos alfaiates. Salvador: Omar G. Editora, Salvador, 1999, pp.59-67.

${ }^{29}$ Idem, p. 157.

${ }^{30}$ Idem, p.151 seg.

31 Idem, p. 155.

32 AAPB vol.35, p.15, cf. TAVARES, L.H.D., op.cit., p.85.

${ }^{33}$ As conjunturas atlânticas, no tocante às perspectivas de Revolução Francesa, foram tratadas na obra de GODECHOT, Jacques. La Grande Nation. Paris: Aubier-Montaigne, 1983.

${ }^{34}$ Informações biográficas em http://fr.wikipedia.org/wiki/Accueil

35 Informações biográficas em http://fr.wikipedia.org/wiki/Accueil

${ }^{36}$ Sobre a reintrodução da escravidão nas colônias francesas e a situação de São Domingos, que se tornaria dois anos depois no Haiti, v. BÉNOT, Y. e DORIGNY, M. (dir.). Rétablissement de l'esclavage dans les colonies françaises. Aux origines de Haiti. Paris, 2003. ${ }^{37}$ DIAS, J. S da Silva. Os primórdios da Maçonaria em Portugal. vol. I, t. 2, 2aㅡ ed., Lisboa: Instituto Nacional de Investigação Científica, 1986, sobretudo o cap. IX. Ver também Diccionario Bibliographico Portuguez. Volumes 1 a 23. Innocencio Francisco da Silva e 
Brito Aranha, edição em CD-ROM, Lisboa: Biblioteca Virtual dos Descobrimentos Portugueses, 09, Comissão Nacional para as Comemorações dos Descobrimentos Portugueses, s.d. ${ }^{38}$ BARROS, F. Borges de. Novos documentos para a História Colonial. Bahia - Brasil. Salvador, 1931, p. 46.

39 TAVARES, L. H. Dias. História da sedição intentada na Bahia em 1798, p. 85.

${ }^{40}$ Sobre este episódio entre Larcher e o navio Polifemo ver a documentação transcrita em Barros, F. Borges de. Novos Documentos para a História Colonial. Salvador: Imprensa Oficial do Estado, 1931, pp. 43-49.

${ }^{41}$ Sobre os aspectos públicos da estada de Larcher na Bahia v. TAVARES, L.H.Dias. História da sedição intentada na Bahia em 1798, pp. 79-87.

${ }^{42}$ Além do Projeto e da Carta transcritos aqui, há mais três cartas de Larcher no mesmo fundo documental do Arquivo da Marinha francesa tratando do episódio baiano, cf, citaçóes a seguir.

${ }^{43}$ Cf. TAVARES, L.H. Dias, 1978, cit.

${ }^{44}$ Cartas de 29 de março e 14 de maio de 1797.

45 Idem, ibidem.

${ }^{46}$ Carta de 14 de maio de 1797.

${ }^{47}$ CESAIRE, Aimé. Toussaint Louverture. La Révolution Française et le problème colonial. Paris: Présence Africaine, 1981; BÉNOT, Yves \& DORIGNY, Marcel (dir.). Rétablissement de l'esclavage dans les colonies françaises. Aux origines de Hä̈ti. Paris: Maisonneuve \& Larosse, 2003; THIBAU, Jacques. Le temps de Saint-Domingue. L'esclavage et la Révolution Française, Paris: Éditions Jean-Claude Lattès, 1989.

${ }^{48}$ Reforçando esta hipótese de engavetamento prévio do pedido, pode-se ler no alto à esquerda da carta o parecer manuscrito de Carnot, endereçado ao ministro da Marinha e das Colônias "pour faire rapport", como se o ministro ainda não tivesse relatado o conteúdo da proposta ao Diretório. O ministro Truguet seria afastado do cargo um mês após esta correspondência de Larcher, no quadro de um amplo remanejamento ministerial.

49 "Diretório" foi o nome dado ao governo executivo que funcionou na França revolucionária durante quatro anos, de 27 de outubro de 1795 a 19 de novembro de 1799 .

50 Décimo-segundo mês do calendário francês iniciado com a instauração da República, em 21 de setembro de 1792, que começava em 18 de agosto e terminava em 17 de setembro. A data corresponde ao dia 24 de agosto.

${ }^{51}$ Quinto ano da República francesa.

52 Nono mês do calendário republicano francês, que começava em 20 de maio e terminava em 18 de junho.

53 Antigo navio de guerra que servia para transporte do material.

${ }^{54}$ O Diretório da República francesa no momento desta carta era composto por: Lazare Carnot, Jean-François Reubell, Paul Barras, Louis-Marie de la Révellière-Lépaux e François de Barthélemy. 55 Trata-se da Constituição do Ano III (1795) então em vigor, que previa um governo republicano colegiado e voto censitário indireto. 


\section{Referências bibliográficas}

ARMITAGE, J. História do Brasil. Belo Horizonte: Itatiaia; São Paulo: Edusp, 1981. ARCHIVES de la Marine, Paris. Série BB4, 1050.

BARROS, F. Borges de. Os Confederados do Partido da Liberdade. Salvador, 1922. BARROS, F. Borges de. Novos documentos para a História Colonial. Bahia - Brasil. Salvador, 1931.

BÉNOT, Y.; DORIGNY, M. (Dir.). Rétablissement de l'esclavage dans les colonies françaises. Aux origines de Haiti. Paris, 2003.

CASCUDO, Luiz da Câmara. O Doutor Barata: politico, democrata e jornalista. Bahia: Imprensa Oficial do Estado, 1938.

CESAIRE, Aimé. Toussaint Louverture. La Révolution Française et le problème colonial. Paris: Présence Africaine, 1981.

DIAS, J. S da Silva. Os primórdios da Maçonaria em Portugal. $2^{\underline{a}}$ ed. Lisboa: Instituto Nacional de Investigação Científica, 1986. v. I, tomo 2.

FURTADO, Junia (Org.). Diálogos Oceânicos: Minas Gerais e as novas abordagens para uma história do Império Ultramarino Português. Belo Horizonte: UFMG, 2001, pp.361-387.

GODECHOT, Jacques. La Grande Nation. Paris: Aubier-Montaigne, 1983.

JANCSÓ, István. A sedução da liberdade: cotidiano e contestação política no final do Século XVIII. In: SOUZA, Laura de Melo e (Org.); NOVAIS, Fernando A. (Dir.). História da Vida Privada no Brasil - Cotidiano e Vida Privada na América Portuguesa. São Paulo: Companhia das Letras, 1997.

JANCSÓ, István. Adendo à discussão da abrangência social da Inconfidência Bahiana de 1798. In: BLAJ, Ilana; MONTEIRO, John. (Org). História e Utopias: textos apresentados no XVII Simpósio Nacional de História. São Paulo: ANPUH, 1996.

JANCSÓ, István. Contrabandos e idéias. In: DOMINGUES, C.V., LEMOS, C.V.; YGLESIAS, E. (Orgs.) Animai-vos, povo bahiense: A conspiração dos alfaiates. Salvador: Omar G. Editora, 1999, pp.59-67.

JANCSÓ, István. Na Bahia, contra o Império: história do ensaio de sedição de 1798. São Paulo: Hucitec, 1996.

JANCSÓ, István. Um problema historiográfico: o legado de D. Fernando José de Portugal. Congresso de História da Bahia, 4., 2001, Salvador. Anais. Salvador: Instituto Geográfico e Histórico da Bahia; Fundação Gregório de Mattos, 2001. v. 1, pp.297-322. 
MOREL, M. Tensões entre revolução e escravismo: o caso de Cipriano Barata em 1798. In: ARAÚJO, U. de Castro (Org.). II Centenário da sedição de 1798 na Bahia. Salvador: Academia de Letras da Bahia, 1999.

RUY, Afonso. A primeira revolução social brasileira (1798). 2aㅡ. São Paulo, 1978. (Brasiliana, v. 217).

SILVA, Accioli de Cerqueira. Memórias históricas e politicas da Provincia da Bahia. Salvador: Imp. Of. do Estado, 1931, 6 v. (1ª ed. 1835-1852), vol. III, p.17 com preciosas anotações de Braz do Amaral.

SILVA, Evaristo L.I. Recordaçôes biographicas do Coronel João Ladisláu de Figueiredo e Mello ordenadas por seu neto Evaristo Ladisláu I. Silva. Bahia: Typ. de C. de L. Masson \& Cia., 1866.

TAVARES, Luís Henrique Dias. História da sedição intentada na Bahia em 1798. São Paulo: Pioneira, 1975. p.95.

THIBAU, Jacques. Le temps de Saint-Domingue. L'esclavage et la Révolution Française, Paris: Éditions Jean-Claude Lattès, 1989.

VARNHAGEN, Francisco A. de. História Geral do Brasil. Belo Horizonte: Itatiaia; São Paulo: Edusp, s.d. vol. III, t.V, p.24-5.

VILHENA, Luis dos Santos. Notícias soteropolitanas e brasilicas. Salvador: Imprensa Oficial do Estado, 1922.

WIKIPÉDIA: L'encyclopédie libre. Disponível em: http://fr.wikipedia.org/wiki/ Accueil

\section{RESUMO}

A publicação e análise da correspondência e de um Projeto de invasão da Bahia enviados pelo capitão da Marinha Antoine-René Larcher ao Diretório da República Francesa em 1797 permitem conhecer, sob novos ângulos, os episódios da chamada Conjuração Baiana, tanto pela abrangência social dos conspiradores, quanto por dimensöes até então desconhecidas pela historiografia de projetos efetivamente inseridos numa perspectiva mais ampla de tentativas de expansão da Revolução Francesa. Palavras-chave: Brasil colônia, Bahia: História, Revolução Francesa, Conjuração Baiana. 


\section{ABSTRACT}

The analysis of correspondence now available on a Plan for the Invasion of Bahia, sent by naval captain Antoine-Rene Larcher to the Directorate of the French Republic in 1797, sheds new light on episodes of the so-called Bahian Conspiracy, as much with respect to the conspirators' social penetration as in regard to aspects of wideranging attempts to to expand the French Revolution previously unknown to historiography.

Keywords: Colonial Brazil, Bahia: History, French Revolution, Bahian Conspiracy.

(recebido em abril 2007 e aprovado em julho do mesmo ano) 